\title{
AUNC
}

Zabytkoznawstwo i Konserwatorstwo XLVII

Toruń 2016

DOI: http://dx.doi.org/10.12775/AUNC_ZiK.2016.007

\section{Polichromie ścienne \\ Wacława Taranczewskiego \\ w kościele pw. św. Jana Chrzciciela w Radomiu}

\author{
ANGELIKA LAMENT-KOSIŃSKA \\ Instytut Zabytkoznawstwa i Konserwatorstwa, Wydział Sztuk Pięknych, UMK w Toruniu \\ e-mail: a.lament@doktorant.umk.pl
}

Keywords: contemporary painting, wall paintings, Waclaw Taranczewski, St. John Baptist Church, Radom

Słowa kluczowe: malarstwo współczesne, polichromie ścienne, malowidła ścienne, Wacław Taranczewski, kościół św. Jana Chrzciciela, Radom

\begin{abstract}
Wall paintings by Waclaw Taranczewski at St. John Baptist Church in Radom

St. John Baptist Church, dating back to the fourteenth century, is one of the most important monuments in Radom, which was renovated numerous times in its history. All of these works have affected on the present character of the Gothic building. Nevertheless, walking inside the church we have a feeling of cohesion and style unity. One of its constant interior design element is contemporary wall paintings by Waclaw Taranczewski, created at 1971-1972. Its feature is a rich religious and historical iconography indicating the importance of St. John Baptist Church and its role in regional and Polish history. The wall paintings are an excellent example of Taranczewski's monumental works. Interior decoration design at St. John Baptist Church seem to be one of the most complete artist's monumental work, especially because it has survived without any transformation that could have been destructive for its historical matter.
\end{abstract}




\begin{abstract}
Abstrakt
Kościół farny pw. św. Jana Chrzciciela, którego historia sięga XIV wieku, jest jednym z najważniejszych zbytków w Radomiu. Jego bryła i wnętrze na przestrzeni minionych stuleci wielokrotnie ulegały przeobrażeniom, co miało znaczący wpływ na obecny charakter gotyckiej budowli. Niemniej jednak wnętrze świątyni charakteryzuje spójność i jedność stylu. Jednym ze stałych elementów wystroju są współczesne polichromie ścienne autorstwa Wacława Taranczewskiego, wykonane w latach 1971-1972. Ich bogata religijna i historyczna treść wskazuje na znaczenie radomskiej fary w historii regionu i Polski. Malowidła te stanowią znakomity przykład monumentalnej sztuki artysty. Realizacja polichromii do wnętrza kościoła pw. św. Jana Chrzciciela w Radomiu zdaje się jedną z jego najbardziej kompletnych realizacji - szczególnie, że przetrwała bez wtórnych przekształceń. Stanowi ostatnie dzieło malarstwa ściennego, przy którym Wacław Taranczewski pracował osobiście, a także swoiste podsumowanie jego działalności w tym zakresie.
\end{abstract}

Kościół pw. św. Jana Chrzciciela jest niewątpliwie jednym z najważniejszych radomskich zabytków. Gotycka świątynia była przez wieki poddawana wielu przebudowom i pracom restauratorskim, mającym wpływ na jej wygląd. Mimo to obecne wnętrze budynku cechuje spójność i jedność stylu. Jednym z elementów wystroju, przypominającym o historii kościoła i decydującym o odbiorze jego wnętrza, są współczesne polichromie ścienne autorstwa Wacława Taranczewskiego.

Historia kościoła św. Jana Chrzciciela sięga XIV wieku. Król Kazimierz Wielki dokonał wtedy lokacji tzw. Nowego Radomia i w pobliżu królewskiego zamku oraz rynku wzniesiono, najprawdopodobniej w latach 1360-13701, miejską farę w stylu gotyckim, z czerwonej cegły². Pierwotnie plan architektoniczny przedstawiał jedną nawę i obniżone w stosunku do niej, orientowane prezbiterium. Pozostałością po tamtej świątyni są mury prezbiterium oraz częściowo zachowane ściany nawy głównej. Kolejne stulecia przynosiły rozbudowy i przekształcenia, w wyniku których kościół zyskał wysoką, czterokondygnacyjną wieżę oraz został powiększony o ciąg kaplic od strony

1 Maria Brykowska i Ryszard Brykowski, „Kościół farny pw. św. Jana Chrzciciela w Radomiu dzieje budowlane i architektura”, w Kościół św. Jana Chrzciciela w Radomiu: architektura, ludzie, wydarzenia, red. Dariusz Kupisz (Radom: Wydawnictwo Naukowe Instytutu Technologii Eksploatacji - PIB, 2010), 98; Jerzy Z. Łoziński i Barbara Wolff, „Powiat radomski”, w Katalog zabytków sztuki w Polsce, t. 3, z. 10 (Warszawa: IS PAN, 1961), 23.

2 Dariusz Kupisz, „Dzieje parafii św. Jana Chrzciciela w Radomiu w XIV-XVIII wieku”, w Kościót św. Jana Chrzciciela, 15-16. 
północnej i południowej³ ${ }^{3}$ Wielokrotnie zmieniał się również wystrój malarski radomskiej fary. Transformacjom sprzyjała nie tylko ewolucja gustów na przestrzeni dziejów, ale także pogarszający się stan zachowania budowli i starania podejmowane w celu jego poprawy ${ }^{4}$.

Obecny charakter i kształt architektoniczny świątyni w dużym stopniu zdeterminowała przebudowa z lat 1908-1909, przeprowadzona według projektu architekta Józefa Piusa Dziekońskiego ${ }^{5}$. Przed przystąpieniem do tych prac kościół był w bardzo złej kondycji - zawilgocony, ze zniszczoną więźbą i pokryciem dachowym, z zaniedbanym wyposażeniem i zniszczonymi polichromiami ściennymi ${ }^{6}$. Zgłaszane były nawet propozycje wyburzenia świątyni ${ }^{7}$. Na szczęście, staraniem ówczesnego proboszcza ks. Piotra Górskiego w lipcu 1908 roku ruszyły szeroko zakrojone prace restauratorskie ${ }^{8}$. Budynek został podwyższony i wydłużony do czterech przęseł w nawie głównej. Ciąg kaplic od strony południowej częściowo wyburzono i przekształcono w nawę boczną - południową, którą podobnie jak kaplicę Różańcową przekryto sklepieniem kryształowym. Nad nawą główną wzniesiono sklepienie sieciowe9 ${ }^{9}$. Dotychczasowe wyposażenie wnętrza zastąpiono nowym, w stylu neogotyckim. Towarzyszyły mu nowe przeszklenia oraz wystrój malarski ścian autorstwa Tadeusza Rychtera i Mariana Kopińskiego ${ }^{10}$. Polichromie te w latach czterdziestych zastąpiono malowidłami pędzla Jana Bukowskiego i profesora Sedliczki z Krakowa ${ }^{11}$. Ostatnie znaczące zmiany w aranżacji wnętrza radomskiej fary przynieść miała druga połowa XX wieku.

We wrześniu 1969 roku w parafii odbyło się spotkanie dotyczące planowanych prac wewnątrz świątyni farnej, w którym wzięli udział między innymi ówczesny proboszcz ks. Jan Węglicki, Wojewódzki Konserwator Zabyt-

3 Brykowska i Brykowski, „Kościół”, 105-107, 115-117; Jan Wiśniewski, Dekanat Radomski (Kielce: Wydawnictwo Jedność, 2000), 208; Tomasz Gola, „Wystrój i wyposażenie kościoła pw. św. Jana Chrzciciela w Radomiu na przestrzeni wieków”, w Kościół św. Jana Chrzciciela, 138-139, 143; Łoziński i Wolff, „Powiat”, 24.

4 Brykowska i Brykowski, „Kościół”, 106 i 118; Gola, „Wystrój”, 146, 149, 155 i 158; Wiśniewski, Dekanat, 212.

5 Artur Hejda i Albert Warso, Kościoły Radomia (Radom: Katedra Radomska, 2006), 50.

6 Szczepan Kowalik, Fabrica ecclesiae. Żywot i sprawy radomskiego proboszcza ks. Piotra Górskiego (Radom: Wydawnictwo Naukowe Instytutu Technologii i Eksploatacji - PIB, 2016), 43-44, 101-103.

Gola, „Wystrój”, 163.

Wiśniewski, Dekanat, 221-223; Kowalik, Fabrica, 103.

9 Brykowska i Brykowski, „Kościół”, 127-134.

10 Brykowska i Brykowski, „Kościół”, 133; Gola, „Wystrój”, 164 i 166.

11 Gola, „Wystrój”, 166. 
ków oraz profesor Wacław Taranczewski ${ }^{12}$. Podkreślając brak historycznych i artystycznych wskazań do zachowania istniejących wówczas polichromii ściennych, zalecono przygotowanie nowego projektu malowideł, który nawiązywałby do wyposażenia wnętrza, wiążąc i scalając poszczególne elementy w konsekwentną całość.

W roku 1970 przystąpiono do prac porządkowych w prezbiterium ${ }^{13}$. Po wykonaniu zaleconych przez Wojewódzkiego Konserwatora Zabytków badań architektonicznych usunięto ze ścian prezbiterium i żeber sklepiennych tynki wraz z istniejącą wówczas polichromią, odsłaniając wątek ceglanego muru $^{14}$. Uszkodzone fragmenty uzupełniono zaprawami imitującymi cegłę lub nowymi licówkami, o wymiarach odpowiadających oryginalnemu budulcowi ${ }^{15}$. Decyzja w sprawie przeprowadzenia prac konserwatorskich w kościele farnym, zastrzegająca autorstwo projektu polichromii ściennych dla Wacława Taranczewskiego, zapadła w sierpniu 1970 roku $^{16}$. W celu ekspozycji i zaakcentowania zabytkowej substancji najstarszej części kościoła, przyjęto do realizacji projekt zakładający wykonanie malowideł w prezbiterium bezpośrednio na wyeksponowanym, autentycznym ceglanym wątku gotyckim ${ }^{17}$. Prace konserwatorskie związane z porządkowaniem architektury w tej części kościoła trwały jeszcze latem 1971 roku. Pod koniec czerwca do wiadomości parafian podano, że w celu wykonania nowych polichromii ks. Węglicki zaangażował profesora krakowskiej Akademii Sztuk Pięknych Wacława Taranczewskiego ${ }^{18}$. W pierwszych dniach lipca, w związku z dobiegającymi końca pracami konserwatorskimi w prezbiterium, Wojewódzki Konserwator

12 Archiwum Wojewódzkiego Urzędu Ochrony Zabytków w Warszawie Delegatura w Radomiu (dalej: AWUOZWDR), teczka Kościół pw. św. Jana Chrzciciela w Radomiu (od 1960) (dalej: TKJCR), 17-18, Protokół spisany 25.09.1969 w Radomiu na temat spraw związanych z zamierzonym projektem polichromii wnętrza, mps.

13 Zgodnie z notatką służbową z 27.01.1971 Wojewódzkiego Konserwatora Zabytków w Kielcach (dalej: WKZK), za: Archiwum parafii pw. św. Jana Chrzciciela w Radomiu (dalej: APJC), Kronika parafii św. Jana Chrzciciela w Radomiu, 1971, rękopis ks. Stanisława Sikorskiego (dalej: Kronika). Za wyszukanie i udostępnienie parafialnych materiałów archiwalnych autorka pragnie podziękować ks. Mirosławowi Nowakowi.

14 Zgodnie z zaleceniami WKZK, zob. AWUOZWDR, TKJCR, 64, Notatka służbowa spisana 3.10.1970 dotycząca ustalenia programu prac konserwatorskich w prezbiterium kościoła farnego w Radomiu poprzedzających wprowadzenie nowej polichromii projektu prof. Taranczewskiego, mps.

15 AWUOZWDR, TKJCR, 97, Notatka służbowa z 23.03.1971, rkps.

16 AWUOZWDR, TKJCR, 58-59, Decyzja o prowadzeniu prac konserwatorskich z 5.08.1970, mps.

17 AWUOZWDR, TKJCR, 68-69, Notatka służbowa z 23.10.1970, mps.

18 APJC, Kronika. 
Zabytków zezwolił na rozpoczęcie realizacji przygotowanego projektu polichromii ${ }^{19}$.

Zachowane źródła archiwalne, jak się zdaje, nie ukazują wszystkich faktów, które pamiętają osoby mające osobisty kontakt z Wacławem Taranczewskim. Według relacji Bronisława Nowaka ${ }^{20}$, ówczesne służby miały przynajmniej początkowo nie być przychylne powstaniu nowych polichromii w radomskiej świątyni. Wprawdzie uznanemu twórcy zezwalano na ryzykowne w tamtym czasie uprawianie sztuki sakralnej oraz współpracę z instytucjami kościelnymi ${ }^{21}$, lecz realizacja projektu została zagrożona problemami na tle politycznym. Spotkania, na których decydowano o powstaniu malowideł w Radomiu, przybierały konspiracyjny charakter. Profesor umawiał się z przedstawicielami Wydziału Kultury Komitetu Centralnego PZPR poza kościołem i parafią farną, w ustalonym czasie i miejscu na trasie Radom-Warszawa, do którego zainteresowani docierali samochodami. Planowane duże zamierzenie artystyczne w ważnym radomskim kościele i bliskość stolicy przyczyniły się prawdopodobnie do szczególnego zainteresowania projektem ze strony władz państwowych, które nie chciały przystać na rozpoczęcie prac $^{22}$. Pomimo początkowych problemów udało się jednak doprowadzić do powstania polichromii.

Wacław Taranczewski zaprosił do udziału w realizacji projektu zespół, w składzie którego znaleźli się jego studenci i współpracownicy: Janina Kraupe-Świderska ${ }^{23}$, Jerzy Lubański, Paweł Taranczewski, Leszek Misiak i Andrzej Herman ${ }^{24}$. Zgodnie z intencją ks. Węglickiego i obietnicą artysty,

19 AWUOZWDR, TKJCR, 108, Notatka służbowa spisana 2.07.1971 w kościele parafialnym w Radomiu w związku z zakończonym etapem porządkowania architektury prezbiterium i przedłożoną alternatywą polichromii prof. Taranczewskiego, rkps.

20 Bronisław Nowak - krakowski kolekcjoner dzieł sztuki, pozostawał w bliskich stosunkach z W. Taranczewskim w związku z regularnym zakupem jego dzieł w latach 1980-1983. Artysta podczas wspólnych spotkań, oprócz komentowania spraw bieżących, poruszał zagadnienia związane z jego wcześniejszą twórczością, zob. Marek Marko, „Prace Wacława Taranczewskiego w kolekcji Bronisława Nowaka”, w Wacław Taranczewski. Pastele 1980-1983 ze zbiorów Bronisława Nowaka i Jarosława Mudyna (Kraków: Aladyn, Bronisław Nowak, 2016), $10-23$.

21 Marko, „Prace”, 12-13.

22 Informacje te autorka uzyskała od p. Bronisława Nowaka, któremu pragnie podziękować za rozmowy przeprowadzone we wrześniu $2016 \mathrm{r}$.

23 Marta Taranczewska, „Kalendarium życia i twórczości Wacława Taranczewskiego”, w Wacław Taranczewski, red. Paweł Taranczewski (Kraków: ASP, 2008), 167.

24 Rozmowa autorki z prof. Pawłem Taranczewskim w styczniu 2017 r.; rozmowa autorki z prof. Leszkiem Misiakiem w styczniu 2017 r. Za życzliwie przekazane informacje autorka serdecznie dziękuje. 
polichromie w prezbiterium miały powstać w okresie od 1 lipca do września 1971 roku. Dobór scen, które znalazły się w tej części świątyni, przypisuje się ówczesnemu proboszczowi ${ }^{25}$. Ze względu na jego pogarszający się stan zdrowia administracyjne obowiązki, w tym zapewne również nadzór nad postępami prac przy polichromiach, przejął pracujący już wówczas przy parafii farnej ks. Stanisław Sikorski, który po śmierci ks. Węglickiego (31 lipca 1971 r.) oficjalnie objął probostwo 27 września tego samego roku ${ }^{26}$. Prace związane z nowym wystrojem wnętrza kontynuowane były w roku następnym. Wykonanie malowideł w nawie kościoła profesor zobowiązał się zakończyć do września 1972 roku $^{27}$.

Monumentalna twórczość Wacława Taranczewskiego ujawnia jego fascynację sztuką średniowieczną, zarówno polską, jak i europejską ${ }^{28}$. Inspiracje, a czasem niemal bezpośrednie odniesienia do konkretnych dzieł historycznych są w jego malarstwie dobrze widoczne. Polichromie w radomskiej farze stanowią kolejną w sztuce Taranczewskiego reminiscencję gotyckich malowideł z kościoła św. Jana Chrzciciela w Gnieźnie ${ }^{29}$. Zamknięcie poszczególnych scen w wyznaczonych ramach, ich pasowy układ, bogata kolorystyka oraz pierwszoplanowe ujęcie postaci przywodzi na myśl również czternasto- i piętnastowieczne europejskie malarstwo ścienne ${ }^{30}$. Forma, jaką nadał swojej radomskiej realizacji, była bez wątpienia uwarunkowana architekturą świątyni. Tej regule podlegały wszystkie monumentalne prace artysty ${ }^{31}$. Ko-

25 APJC, Kronika.

26 Dariusz Kupisz, „Proboszczowie parafii pw. św. Jana Chrzciciela w Radomiu w XIX-XXI wieku”, w Kościół św. Jana Chrzciciela, 81 i 83.

27 APJC, Kronika.

28 W latach 1935 i 1937 artysta odwiedził m.in. Francję, Włochy i Grecję; zob. Ewa Herniczek, „Wacław Taranczewski”, w Wacław Taranczewski, 14; Zdzisław Kępiński, Wacław Taranczewski (Poznań: Muzeum Narodowe, 1958), 33-35 i 41-43.

29 Powiązań z gotyckimi malowidłami z Gniezna można się doszukiwać przede wszystkim w prezbiterium, gdzie artysta na wzór średniowiecznych obrazów wykorzystał wątek ceglany jako tło dla swoich przestawień. Po raz pierwszy zastosował ten sposób w latach 50. w kościele pw. św. Marcina w Poznaniu, zob. Kępiński, Wacław, 60-61; Iwona Błaszczyk, „Wacław Taranczewski i jego wizja wnętrza kościoła św. Marcina”, Kronika Miasta Poznania 1 (2006): 60-86.

30 Zob. Ewa Herniczek, „Malarstwo monumentalne Wacława Taranczewskiego - pytanie o nowoczesność”, w Wobec przyszłości. Materiały nadesłane i wygłoszone na sesji naukowej z okazji 185-lecia działalności Akademii Sztuk Pięknych w Krakowie 12.12.2003 - 15.12.2003, red. Janusz Krupiński i Paweł Taranczewski (Kraków: ASP, 2004), 271-272.

31 Zob. Józef Tadeusz Gawłowski, „O związkach między malarstwem i architekturą w 175-letnich dziejach Akademii Sztuk Pięknych w Krakowie”, w 175 lat nauczania malarstwa, rzeźby i grafiki w krakowskiej Akademii Sztuk Pięknych, red. Józef Lucjan Ząbkowski et al. (Kraków: Oficyna Artystów Sztuka, 1994), 94-96; Herniczek, „Malarstwo”, 268 i 269-270. 
nieczność dostosowania nowych polichromii do wnętrza radomskiej fary wielokrotnie podkreślano również w trakcie prac przygotowawczych. Od projektu Wacława Taranczewskiego wymagano, aby nie tylko nie zakłócał estetycznego odbioru wnętrza, ale wyeksponował jego walory, harmonizował z całym wystrojem i podkreślił historyczną rangę świątyni ${ }^{32}$. Kolejną z ogólnych zasad przyjętych przez artystę w radomskiej farze była czytelność wprowadzanych form $^{33}$. Mając świadomość tworzenia we wnętrzu użyteczności publicznej, Wacław Taranczewski zadbał, by jego przekaz był zrozumiały dla odbiorców. Temu celowi służyć miało opatrzenie poszczególnych postaci inskrypcjami. Przestrzegając reguły czytelności form artysta wyszedł także naprzeciw postulatom strony kościelnej o łatwą rozpoznawalność przedstawień ${ }^{34}$.

Duży wpływ na ideową treść zawartą w malowidłach miał niewątpliwie zleceniodawca, ale ostatecznego wyboru scen oraz sposobu ich ujęcia dokonywał artysta. Zgodnie z przyjętą zasadą jasności i czytelności przekazu starał się dobierać dla danego wątku ujęcia najbardziej reprezentatywne ${ }^{35}$. Ze względu na rangę zabytkowego kościoła farnego wypracowanie koncepcji i właściwego projektu dla radomskich polichromii wymagało dużego wysiłku. Projekt został przedstawiony nie tylko ówczesnemu proboszczowi, ks. Węglickiemu, ale także w Wojewódzkim Urzędzie Ochrony Zabytków w Kielcach oraz w kurii diecezji sandomierskiej, którym wówczas parafia podlegała. Profesor przygotował kilka propozycji rozwiązań dla poszczególnych części kościoła $^{36}$. Jedna $\mathrm{z}$ wersji projektu uwzględniała na sklepieniu dekorację roślinną, która szczególnie przypadła do gustu ks. Węglickiemu. Taranczewski opowiadał się jednak zdecydowanie po stronie koncepcji z przedstawieniami figuralnymi ${ }^{37}$, którą ostatecznie przyjęto do realizacji. Po wstępnych konsul-

32 Zob. AWUOZWDR, TKJCR, 32-38, Ryszard Brykowski, Wytyczne do postępowania konserwatorskiego, maj 1970, mps; AMWUOZDR, TKJCR, 17-18, Protokół spisany 25.09.1969.

33 Zob. Barbara Odrobny, „Sakralne malarstwo monumentalne Wacława Taranczewskiego” (praca magisterska, Instytut Historii Sztuki, Wydział Historyczny, Uniwersytet Jagielloński, 1993), 85; Herniczek, „Malarstwo”, 271. E. Herniczek w swojej pracy w znacznej mierze powtarza ustalenia z pracy B. Odrobny.

34 AWUOZWDR, TKJCR, 43, List Diecezjalnej Komisji Budowlanej w Sandomierzu do Kurii Diecezjalnej w Sandomierzu z 23.05.1970, mps.

35 Odrobny, „Sakralne malarstwo”, 85; Herniczek, „Malarstwo”, 271, 277-278.

36 Zob. AWUOZWDR, TKJCR, 50, List WKZK do W. Taranczewskiego z 2.06.1970, mps.

37 Taranczewski wystosował nawet list, w którym prosił o poparcie dla lepszego według niego projektu i przekonanie do tej koncepcji proboszcza ks. Węglickiego, zob. AWUOZWDR, TKJCR, 44, List W. Taranczewskiego z 24.05.1970, najprawdopodobniej do WKZK, rkps. 
tacjach i omówieniu projektów artysta nie zwykł pozwalać zleceniodawcy na ingerencję w proces twórczy ${ }^{38}$.

Do prezbiterium radomskiego kościoła farnego Wacław Taranczewski zaprojektował cykl trzynastu scen z Nowego Testamentu. Z wyjątkiem dwóch scen w górnej partii ściany północnej, zamkniętych ostrołukowo, każda z pozostałych jest obwiedziona cienką białą linią wyznaczającą prostokątne pole przedstawienia. Sceny zostały umieszczone w trzech rzędach, czytanych od lewej do prawej począwszy od dolnego rzędu. Osiem przedstawień w najniższym rzędzie dotyczy bezpośrednio dziejów św. Jana Chrzciciela. Patron świątyni ukazany został w charakterystycznym, typowym dla ikonografii chrześcijańskiej odzieniu z wielbłądziej sierści i skórzanym pasie. Ponieważ artysta wielokrotnie w swojej pracy tworzył polichromie do kościołów pod wezwaniem św. Jana Chrzciciela ${ }^{39}$, w radomskich malowidłach można doszukiwać się analogii, a może nawet bezpośrednich przeniesień z układów już wcześniej przez niego zastosowanych. Szczególne podobieństwa cyklu poświęconego życiu patrona parafii są widoczne pomiędzy malowidłami radomskimi a znajdującymi się w kościele św. Jana Chrzciciela w Kupnie ${ }^{40}$. Projekt polichromii dla kościoła farnego był dla Wacława Taranczewskiego kolejnym wyzwaniem do podjęcia tego samego tematu i uzyskania innego efektu końcowego. W każdej bowiem jego realizacji o podobnej tematyce znajdujemy pewne, choćby niewielkie zmiany kompozycyjne. Działanie takie całkowicie wpisuje się w metodę twórczą artysty, który zwykł wielokrotnie powracać do tych samych układów i tematów, rozwiązując je za każdym razem w odmienny sposób ${ }^{41}$.

38 Odrobny, „Sakralne”, 85; Herniczek, „Malarstwo”, 271 i 277-278.

39 Kościoły pw. św. Jana Chrzciciela w Radłowie, Krotoszynie, Paczkowie, Kupnie, a także kaplica Zmartwychwstania w katedrze św. Jana Chrzciciela we Wrocławiu - gdzie jednak tematyka przedstawień dotyczy m.in. wezwania kaplicy, zob. Marta Taranczewska, „Prace monumentalne”, w Wacław Taranczewski, 173.

40 Zob. Odrobny, „Sakralne malarstwo”, 100-101; Herniczek, „Malarstwo”, 286. Malowidła w kościele pw. św. Jana Chrzciciela w Kupnie, w przeciwieństwie do zachowanych w oryginalnej postaci w Radomiu, zostały przemalowane po formie. Prowadzone przez autorkę badania dowodzą, że wykonana renowacja w znaczący sposób zmieniła charakter i kolorystykę pierwotnego założenia artysty (kompozycja nie uległa istotnym zmianom).

41 Zob. Paweł Taranczewski, „Drogi Wacława Taranczewskiego”, Estetyka i Krytyka 6 (2004) 1: 1-8, http://estetykaikrytyka.pl/art/6/Taranczewski.pdf (dostęp: 24 marca 2016); Franciszek Chmielowski, „Mistrz integralnej wyobraźni”, w Wacław Taranczewski, 44-51; Herniczek, „Wacław”, 10-43. 
Analogie kompozycyjne do wcześniejszych monumentalnych realizacji Wacława Taranczewskiego odnajdziemy także w pozostałych polichromiach z radomskiej świątyni. Ich przykładem są z pewnością sceny związane z najważniejszymi wydarzeniami z Nowego Testamentu, które widnieją na pięciu obrazach umieszczonych nad cyklem malowideł poświęconych Janowi Chrzcicielowi. Przedstawienia choćby Ostatniej Wieczerzy, a także Przekazania kluczy św. Piotrowi - często powtarzające się w malarstwie ściennym Taranczewskiego - odnoszą się tu do pierwowzoru z kościoła pw. św. Marcina w Poznaniu ${ }^{42}$. Echo tamtych polichromii brzmi w prezbiterium radomskiej fary szczególnie głośno ze względu na ponowne wykorzystanie jako podłoża ceglanego wątku. Zaakcentowano budowę muru z pojedynczych elementów, składających się na rozedrgane tło, różnicując ton poszczególnych cegieł podmalowaniem. Kontur postaci podkreślony został za pomocą żelazistoczerwonej i brązowej linii. Plamy barwne kładzione są płasko. Paleta jest szeroka - od jaskrawych i świetlistych czerwieni, oranżów, błękitów, fioletów, turkusów i zieleni przez brązy i ugry do stonowanych szarości, kolory zaś często zestawiane na zasadzie kontrastów. Postaci są smukłe, o nieco wydłużonych proporcjach, a ich szaty mocno udrapowane, co wzmacnia efekt dekoracyjności.

W podziałach sklepienia prezbiterium, podkreślonych czerwoną linią biegnącą wzdłuż ceglanych żeber i ścian, na białym, tynkowanym tle namalowano głowy dwudziestu dwóch Mężów ze Starego i Nowego Testamentu. Wcześniej przedstawienia starotestamentowych scen lub pojedynczych postaci pojawiły się w malarstwie ściennym Wacława Taranczewskiego tylko w Krotoszynie i Gostyniu. Podobnie jak tam, głowy proroków ukazane na sklepieniu prezbiterium radomskiej fary mają wskazywać na obecność w tabernakulum Chrystusa, którego przyjście zapowiadali ${ }^{43}$. Ich wizerunki, umieszczone w dolnych partiach wysklepków, zostały potraktowane syntetycznie, konturowo, za pomocą ciemnej, zielonkawoczarnej farby. Zgodnie z zasadą czytelności przedstawień, każdej postaci towarzyszy imię, zapisane wielkimi literami stylizowaną czcionką w czerwonym kolorze.

W górnych partiach sklepienia widnieje osiem postaci grających aniołów, potraktowanych podobnie jak głowy mężczyzn. Ciemny rysunek ich mocno

42 Odrobny, „Sakralne malarstwo”, 89-90 i 93; Herniczek, „Malarstwo”, 280 i 282; Błaszczyk, „Wacław”, 60-86.

43 Odrobny, „Sakralne malarstwo”, 86-88; Herniczek, „Malarstwo”, 279. 
udrapowanych i rozwianych szat został podkreślony w miejscach lamówek jasnożółtym, oranżowym lub niebieskim podbarwieniem. Instrumenty muzyczne, na których przygrywają aniołowie, wypełniono oranżem lub jasnym żółcieniem. Podobnie kolorem niebieskim lub żółtym podkreślono rozwiane, dekoracyjne wstęgi. Pozostałe wysklepki, na których nie przewidziano postaci aniołów, pokrywa pięć medalionów wyznaczonych podwójną czerwoną linią z symbolami eucharystycznymi.

Przedstawienia na sklepieniach wykonano w bardzo uproszczony, syntetyczny sposób, ale w ich opracowaniu można się dopatrzeć cech charakterystycznych dla wielu realizacji Wacława Taranczewskiego. Linie rysunku oraz jego kolorowe wypełnienie zostały poprowadzone szybko, pewnymi pociągnięciami pędzla. Barwy nachodzą na siebie bądź też pewne partie pozostają celowo „niedomalowane”. Obserwując polichromie z dużej odległości nie sposób wychwycić tych niuansów, które wpływają jednak na ostateczny efekt wizualny. Stanowią ponadto o wyjątkowości i indywidualności dzieł malarstwa monumentalnego artysty, jak się wydaje - pomimo starannego przygotowania projektów i kartonów - niepozbawionych elementu spontaniczności procesu twórczego.

Malowidła na ścianach nawy głównej wykonano w całości na wyprawach tynkowych, na jasnych, monochromatycznych tłach. Ich stylistyka różni się od polichromii w prezbiterium, choć rysunek i wykorzystanie czarnego konturu do jego podkreślenia są podobne. Karnacje namalowano przy wykorzystaniu koloru podłoża, czasem tylko mocniej lub słabiej go przełamując. Dekoracyjne udrapowanie szat podkreślono dodatkowo białym rysunkiem. Przedstawienia są częściowo malowane płasko - jak na ścianie tęczowej, częściowo bardziej impastowo - na ścianach północnej i południowej. Wykorzystano tu intensywne, mocno nasycone, wręcz jaskrawe kolory, przeplatające się ze sobą spontanicznie w szatach postaci i tworzące rozedrgane wzory tkanin.

Polichromie ściany tęczowej przedstawiają w trzech scenach tematykę pasyjną. Ich centrum zajmuje grupa Ukrzyżowania. Na południowej i północnej ścianie nawy głównej widnieje poczet królów i książąt polskich oraz zasłużonych Polaków, świętych i błogosławionych, którzy związani byli z ziemią radomską. Wacław Taranczewski zaprojektował po pięć postaci na obie ściany do każdego z czterech przęseł nawy, poza północną ścianą czwartego przęsła, gdzie znalazły się dwie postacie. Nawę ozdabia więc szereg trzydziestu siedmiu sylwetek - siedemnastu po stronie północnej i dwudziestu po 
stronie południowej ${ }^{44}$. Postacie zostały ujęte w prostokątne czerwone ramki $\mathrm{z}$ białym tłem, oddzielającym się od piaskowego koloru ścian. Wszystkie sylwetki namalowano w pozie stojącej z odpowiednimi atrybutami, w sposób syntetyczny, posługując się czarnym i czerwonym konturem, który wypełniono jaskrawymi barwami. Farbę nakładano szybkimi i krótkimi pociągnięciami pędzla, miejscami tworząc widoczne impasty. Przeważają tony ciepłe, głównie czerwienie, oranże i żółcienie, ale pojawiają się również błękity oraz sporadycznie zielenie. Najjaśniejsze światła zaznaczone zostały czystą bielą. Każda z postaci jest opisana imieniem stylizowaną czcionką w czarnym kolorze, $\mathrm{z}$ inicjałami podkreślonymi czerwienią.

Nieprzypadkowo poczet ten został namalowany w radomskiej farze, biorąc pod uwagę jej bogate dzieje, a także okres, w jakim polichromie powstały. Przedstawione na ścianach nawy sylwetki królów i książąt polskich oraz zasłużonych Polaków, świętych i błogosławionych miały niewątpliwie przypominać parafianom o historii minionych wieków oraz roli Kościoła katolickiego, jaką w niej odegrał. W postaciach wielkich przodków, którzy oddawali swe modlitwy Bogu w radomskiej świątyni ${ }^{45}$, upatrywać można przekazu patriotycznego, przypomnienia o bogatej historii narodowej. Taki dobór przedstawień jest przypisywany ks. Sikorskiemu ${ }^{46}$, działającemu w konspiracji kapelanowi Armii Krajowej, patriocie i społecznikowi zrzeszającemu ludzi wokół Kościoła ${ }^{47}$. Nie można jednak wykluczyć, że program ikonograficzny nawy zasugerował artyście ks. Węglicki - inicjator nowej aranżacji wnętrza - jeszcze w trakcie uzgadniania wystroju w latach 1969-1971. Pomysłodawcą fryzu mógł być również Wacław Taranczewski, wcześniej wielokrotnie wykorzystujący w swym malarstwie ściennym wizerunki świętych i błogosławionych oraz królów i książąt, którzy odegrali znaczącą rolę w historii Polski i Kościoła katolickiego ${ }^{48}$. Należy jednak pamiętać, że propozycje twórcy musiały pozostawać w zgodzie z poglądami i postulatami zleceniodawcy.

44 Według relacji jednego ze współpracowników W. Taranczewskiego, Leszka Misiaka, podmalowanie ciągu postaci na bocznych ścianach nawy głównej wykonał Jerzy Lubański. Ich wykończeniem zajął się osobiście W. Taranczewski: rozmowa z prof. Leszkiem Misiakiem.

45 W radomskiej farze wielokrotnie bywali m.in. Kazimierz Wielki, Władysław Jagiełło z królową Jadwigą, Kazimierz Jagiellończyk, Stefan Batory, zob. Agnieszka Kozdęba, red., 650 lat radomskiej fary, Muzeum im. Jacka Malczewskiego w Radomiu (Radom: Stowarzyszenie Przyjaciół Radomskiej Fary, 2010), 8-9.

46 APJC, Decyzja nr 688/2015 w sprawie wpisania zabytku do rejestru zabytków, Mazowiecki Wojewódzki Konserwator Zabytków, Warszawa 24.07.2015.

47 Kupisz, „Proboszczowie”, 82-83.

48 Zob. Odrobny, „Sakralne malarstwo”, 102; Herniczek, „Malarstwo”, 287. 
Poniżej cyklu wielkich Polaków oraz świętych i błogosławionych namalowano na ścianach nawy głównej herby dawnych ziem Rzeczypospolitej. Umieszczono je w tarczach sercowych i opatrzono białymi szarfami z opisem. $\mathrm{Na}$ ścianie chóru organowego namalowano natomiast pieczęcie historycznie połączonych ze sobą miast - Radomia i Sandomierza.

Na ścianie północnej w trzecim przęśle nawy głównej, w zamkniętej ostrym łukiem wnęce poniżej wizerunków zasłużonych Polaków znajduje się obraz przedstawiający Wniebowzięcie Najświętszej Marii Panny. Malowidło to Wacław Taranczewski miał wykonać własnoręcznie ${ }^{49}$. Stylistycznie nawiązuje ono do pozostałych polichromii nawy głównej, choć postacie są nieco swobodniejsze, w bardziej naturalnych pozach - szczególnie w dolnej partii obrazu. W części tej przedstawiono dwunastu apostołów przybyłych do grobu Marii, na którym rosną białe lilie - ikonograficzny symbol Matki Bożej. Górna część ukazuje Koronację Najświętszej Marii Panny, której dokonują Chrystus i Bóg Ojciec w otoczeniu dwóch aniołów. Analiza stylistyczna poszczególnych partii malowidła pozwala dostrzec pewne niuanse w rysunku i modelunku. Różnice widoczne są szczególnie w ukazaniu stóp i dłoni. W scenie dolnej namalowano je bardziej swobodnie, z większym wyczuciem. Na tej podstawie można przypuszczać, że Wacław Taranczewski wykonał jedynie dolną partię malowidła, przedstawiającą apostołów u grobu Marii ${ }^{50}$.

Sklepienie w nawie głównej potraktowano analogicznie do sklepienia w prezbiterium. Namalowano na nim czterdzieści dwie głowy świętych oraz szesnaście postaci anielskich. Sylwetki aniołów, podobnie jak w prezbiterium, zostały ukazane w dynamicznych pozach, z instrumentami muzycznymi o żółtych i oranżowych wypełnieniach. Ich rozwiane sukienki nie są jednak tylko delikatnie zaakcentowane kolorem, ale całe wypełnione różnymi odcieniami zieleni lub błękitu.

Scena Przemienienia Pańskiego na zachodniej ścianie kaplicy Różańcowej jest umieszczona, podobnie jak przedstawienie Wniebowzięcia Najświętszej Marii Panny, w polu wyznaczonym czerwoną linią i zamkniętym od góry ostrołukowo. Malowidło to odbiega od charakteru pozostałych polichromii. Jego tonacja jest ciemniejsza, a wypełnienie barwne postaci bardziej płaskie

49 Taranczewska, „Kalendarium”, 167.

50 Górną część malowidła wykonał prawdopodobnie Jerzy Lubański: rozmowa z prof. Leszkiem Misiakiem. 
i jednolite ${ }^{51}$. W bardziej graficzny sposób, ale z wykorzystaniem podobnych głębokich barw zbudowane zostały sylwetki czterech postaci - św. Wandy Malczewskiej, św. Tomasza z Akwinu, św. Małgorzaty Marii Alacoque oraz Jezusa z Otwartym Sercem, namalowane na północnej ścianie kaplicy.

Analizując malarski wystrój wnętrza fary, warto zwrócić uwagę także na dopełniające całości stacje Drogi Krzyżowej. Choć nie są sygnowane, nie pozostawiają wątpliwości co do swojego pochodzenia. Nie jest to pierwszy przykład projektu i wykonania przez Taranczewskiego elementów wystroju wnętrza sakralnego innych niż polichromie ścienne i witraże ${ }^{52}$. Wszelkie wątpliwości co do autorstwa stacji Drogi Krzyżowej z radomskiej fary rozwiewa dokument sporządzony podczas wizytacji biskupiej z 1974 roku. Stanowi on jednocześnie podsumowanie i dowód aprobaty dla rozpoczętych przez ks. Węglickiego i zakończonych przez ks. Sikorskiego prac remontowych, ujęte w następujące słowa: „Oryginalną polichromię, odpowiadającą stylowi świątyni, szczególnie w prezbiterium, projektował i wykonał łącznie ze stacjami Drogi Krzyżowej p. Prof. W. Taranczewski. Kazimierzowska Fara doczekała się poważnej, gustownej szaty i estetycznego wystroju"53.

Polichromie Wacława Taranczewskiego w kościele farnym w Radomiu zdobią niemal całe wnętrze. Ich bogata treść religijno-historyczna i stylistyka utrzymana w duchu regotyzacji podkreśla rangę świątyni oraz jej rolę w dziejach Polski i regionu. Dostosowanie stylistyki malarskiego wystroju i zintegrowanie go $\mathrm{z}$ charakterem wielokrotnie przebudowywanego gotyckiego kościoła stanowiło jedno z najważniejszych zadań zleconych artyście przez farnych duszpasterzy oraz nadzorujące prace służby konserwatorskie. Wrażenie jednolitości stylu, jakie sprawia wnętrze świątyni, przekonuje, że cel ten udało się osiągnąć. Na tle całego imponującego dorobku Wacława Taranczewskiego w zakresie sztuki monumentalnej, cykl polichromii w ko-

51 Różnice w charakterze malowideł wynikają z indywidualnych cech malarstwa poszczególnych osób pracujących w zespole W. Taranczewskiego. Według relacji Pawła Taranczewskiego oraz Leszka Misiaka, wykonanie całej dekoracji kaplicy Różańcowej artysta powierzył Janinie Kraupe-Świderskiej: rozmowa z prof. Pawłem Taranczewskim; rozmowa z prof. Leszkiem Misiakiem.

52 Najbardziej znanym przykładem jest ołtarz pochodzący z kościoła Najświętszej Marii Panny na Ostrowie Tumskim, obecnie w kościele św. Anny w Poznaniu. Stylistyka stacji Drogi Krzyżowej z Sanktuarium Przemienienia Pańskiego w Cmolasie (w woj. podkarpackim), gdzie znajdują się zaprojektowane przez W. Taranczewskiego polichromie, także wskazuje na jego autorstwo.

53 APJC, Protokół wizyty pasterskiej w parafii św. Jana Chrzciciela w Radomiu, sporządzony 3.10.1974, podpisany przez bp. Piotra Gołębiowskiego, mps. 
ściele pw. św. Jana Chrzciciela w Radomiu - warto podkreślić, że zachowany bez wtórnych przekształceń - wydaje się jednym z najpełniejszych. Stanowi także ostatnie dzieło malarstwa ściennego, przy którego realizacji artysta pracował osobiście.

W roku 2015, staraniem obecnego proboszcza ks. Mirosława Nowaka, malowidła w radomskiej farze ze względu na wartości historyczne, religijne i patriotyczne, jakie reprezentują, zostały wpisane do rejestru zabytków ${ }^{54}$. Tym samym stały się najmłodszą monumentalną realizacją Wacława Taranczewskiego objętą ochroną prawną z mocy ustawy o ochronie zabytków.

\section{Bibliografia}

\section{Materiały archiwalne}

Archiwum Wojewódzkiego Urzędu Ochrony Zabytków w Warszawie Delegatura w Radomiu (AWUOZWDR): Teczka kościoła pw. św. Jana Chrzciciela w Radomiu (od 1960) (TKJCR): 17-18, Protokół spisany 25.09.1969 w Radomiu na temat spraw związanych z zamierzonym projektem polichromii wnętrza, maszynopis; 32-38, Ryszard Brykowski, Wytyczne do postępowania konserwatorskiego. Maj 1970, maszynopis; 43, List Diecezjalnej Komisji Budowlanej w Sandomierzu do Kurii Diecezjalnej w Sandomierzu z 23.05.1970, maszynopis; 44, List Wacława Taranczewskiego z 24.05.1970, skierowany najprawdopodobniej do Wojewódzkiego Konserwatora Zabytków w Kielcach (WKZK), rękopis; 50, List WKZK do Wacława Taranczewskiego z 2.06.1970, maszynopis; 58-59, Decyzja WKZK o prowadzeniu prac konserwatorskich z 5.08.1970, WKZK, maszynopis; 64, Notatka służbowa spisana 3.10.1970 dotycząca ustalenia programu prac konserwatorskich w prezbiterium kościoła farnego w Radomiu poprzedzających wprowadzenie nowej polichromii projektu prof. Taranczewskiego. WKZK, maszynopis; 68-69, Notatka służbowa z 23.10.1970. WKZK, maszynopis; 108, Notatka służbowa spisana 2.07.1971 w kościele parafial-

54 Decyzja nr 688/2015 w sprawie wpisania zabytku do rejestru zabytków; w procesie uczestniczyła także autorka. Zob. AWUOZWDR, Karta ewidencyjna zabytku ruchomego, Radom 2014, Angelika Lament-Kosińska, „Polichromie ścienne w kościele farnym pw. św. Jana Chrzciciela, Radom”. Wiosną 2015 r. rozpoczęto pierwszy etap prac konserwatorsko-restauratorskich, których malowidła wymagają ze względu na zły stan techniczny i estetyczny; zob. Angelika Lament-Kosińska i Krzysztof Kosiński, „Program prac konserwatorskich i restauratorskich. Polichromie ścienne Wacława Taranczewskiego w kościele farnym pw. św. Jana Chrzciciela w Radomiu" (projekt prac konserwatorskich, Radom 2015, AMWUOZDR); Angelika Lament-Kosińska i Krzysztof Kosiński, „Dokumentacja prac konserwatorskich i restauratorskich. Polichromie na sklepieniu kościoła farnego pw. św. Jana Chrzciciela w Radomiu autorstwa Wacława Taranczewskiego, 1971" (dokumentacja konserwatorska, Radom 2015, AMWUOZDR). 
nym w Radomiu w związku z zakończonym etapem porządkowania architektury prezbiterium i przedłożoną alternatywą polichromii prof. Taranczewskiego. WKZK, rękopis; 97, Notatka służbowa z 23.03.1971. WKZK, rękopis.

Archiwum parafii pw. św. Jana Chrzciciela w Radomiu (APJC): Ks. Stanisław Sikorski, Kronika parafii św. Jana Chrzciciela w Radomiu, 1971, rękopis; Protokół wizyty pasterskiej w parafii św. Jana Chrzciciela w Radomiu, sporządzony 3.10.1974, podpisany przez bp. Piotra Gołębiowskiego, maszynopis; Decyzja nr 688/2015 w sprawie wpisania zabytku do rejestru zabytków. Mazowiecki Wojewódzki Konserwator Zabytków. Warszawa 24.07.2015.

\section{Druki i opracowania}

Błaszczyk, Iwona. „Wacław Taranczewski i jego wizja wnętrza kościoła św. Marcina”. Kronika Miasta Poznania 1 (2006): 60-86.

Brykowska, Maria, i Ryszard Brykowski. „Kościół farny pw. św. Jana Chrzciciela w Radomiu - dzieje budowlane i architektura”. W Kościół św. Jana Chrzciciela w Radomiu: architektura, ludzie, wydarzenia, red. Dariusz Kupisz, 87-135. Radom: Wydawnictwo Naukowe Instytutu Technologii Eksploatacji - PIB, 2010.

Chmielowski, Franciszek. „Mistrz integralnej wyobraźni”. W Wacław Taranczewski, red. Paweł Taranczewski, 44-51. Kraków: ASP, 2008.

Gawłowski, Józef Tadeusz. „O związkach między malarstwem i architekturą w 175-letnich dziejach Akademii Sztuk Pięknych w Krakowie”. W 175 lat nauczania malarstwa, rzeźby i grafiki w krakowskiej Akademii Sztuk Pięknych, red. Józef Lucjan Ząbkowski, Jerzy Nowakowski, Stanisław Rodziński, Ignacy Trybowski, Stanisław Wejman, Adam Wsiołkowski, 87-106. Kraków: Oficyna Artystów Sztuka, 1994.

Gola, Tomasz. „Wystrój i wyposażenie kościoła pw. św. Jana Chrzciciela w Radomiu na przestrzeni wieków”. W Kościół św. Jana Chrzciciela w Radomiu: architektura, ludzie, wydarzenia, red. Dariusz Kupisz, 137-169. Radom: Wydawnictwo Naukowe Instytutu Technologii Eksploatacji - PIB, 2010.

Hejda, Artur, i Albert Warso. Kościoły Radomia. Radom: Katedra Radomska, 2006.

Herniczek, Ewa. „Malarstwo monumentalne Wacława Taranczewskiego - pytanie o nowoczesność". W Wobec przyszłości. Materiały nadesłane i wygłoszone na sesji naukowej z okazji 185-lecia działalności Akademii Sztuk Pięknych w Krakowie 12.12.2003-15.12.2003, red. Janusz Krupiński i Paweł Taranczewski, 255-300. Kraków: ASP, 2004.

Herniczek, Ewa. „Wacław Taranczewski”. W Wacław Taranczewski, red. Paweł Taranczewski, 10-42. Kraków: ASP, 2008.

Kępiński, Zdzisław. Wacław Taranczewski. Poznań: Muzeum Narodowe, 1958.

Kowalik, Szczepan. Fabrica ecclesiae. Żywot i sprawy radomskiego proboszcza ks. Piotra Górskiego. Radom: Wydawnictwo Naukowe Instytutu Technologii i Eksploatacji PIB, 2016. 
Kozdęba, Agnieszka, red. 650 lat radomskiej fary, Muzeum im. Jacka Malczewskiego w Radomiu. Radom: Stowarzyszenie Przyjaciół Radomskiej Fary, 2010.

Kupisz, Dariusz. „Dzieje parafii św. Jana Chrzciciela w Radomiu w XIV-XVIII wieku”. W Kościół św. Jana Chrzciciela w Radomiu: architektura, ludzie, wydarzenia, red. Dariusz Kupisz, 13-60. Radom: Wydawnictwo Naukowe Instytutu Technologii Eksploatacji - PIB, 2010.

Kupisz, Dariusz. „Proboszczowie parafii pw. św. Jana Chrzciciela w Radomiu w XIX-XXI wieku”. W Kościót św. Jana Chrzciciela w Radomiu: architektura, ludzie, wydarzenia, red. Dariusz Kupisz, 61-86. Radom: Wydawnictwo Naukowe Instytutu Technologii Eksploatacji - PIB, 2010.

Lament-Kosińska, Angelika. „Polichromie ścienne w kościele farnym pw. św. Jana Chrzciciela, Radom”. Karta ewidencyjna zabytku ruchomego, Radom 2014, Archiwum Wojewódzkiego Urzędu Ochrony Zabytków w Warszawie Delegatura w Radomiu.

Lament-Kosińska, Angelika, i Krzysztof Kosiński. „Dokumentacja prac konserwatorskich i restauratorskich. Polichromie na sklepieniu kościoła farnego pw. św. Jana Chrzciciela w Radomiu autorstwa Wacława Taranczewskiego, 1971”. Dokumentacja konserwatorska, Radom 2015, Archiwum Wojewódzkiego Urzędu Ochrony Zabytków w Warszawie Delegatura w Radomiu.

Lament-Kosińska, Angelika, i Krzysztof Kosiński. „Program prac konserwatorskich i restauratorskich. Polichromie ścienne Wacława Taranczewskiego w kościele farnym pw. św. Jana Chrzciciela w Radomiu”. Projekt prac konserwatorskich, Radom 2015, Archiwum Wojewódzkiego Urzędu Ochrony Zabytków w Warszawie Delegatura w Radomiu.

Łoziński, Jerzy Z., i Barbara Wolff. „Powiat radomski”. W Katalog zabytków sztuki w Polsce. T. 3, z. 10. Warszawa: IS PAN, 1961.

Marko, Marek. „Prace Wacława Taranczewskiego w kolekcji Bronisława Nowaka”. W Wacław Taranczewski. Pastele 1980-1983 ze zbiorów Bronisława Nowaka i Jarosława Mudyna, 10-23. Kraków: Aladyn, Bronisław Nowak, 2016.

Odrobny, Barbara. „Sakralne malarstwo monumentalne Wacława Taranczewskiego”. Praca magisterska, Instytut Historii Sztuki, Wydział Historyczny, Uniwersytet Jagielloński, 1993.

Taranczewska, Marta. „Kalendarium życia i twórczości Wacława Taranczewskiego”. W Wacław Taranczewski, red. Paweł Taranczewski, 156-169. Kraków: ASP, 2008.

Taranczewska, Marta. „Prace monumentalne”. W Wacław Taranczewski, red. Paweł Taranczewski, 173. Kraków: ASP, 2008.

Taranczewski, Paweł. „Drogi Wacława Taranczewskiego”. Estetyka i Krytyka 6 (2004) 1. http://estetykaikrytyka.pl/art/6/Taranczewski.pdf. Dostęp 24 marca 2016. 


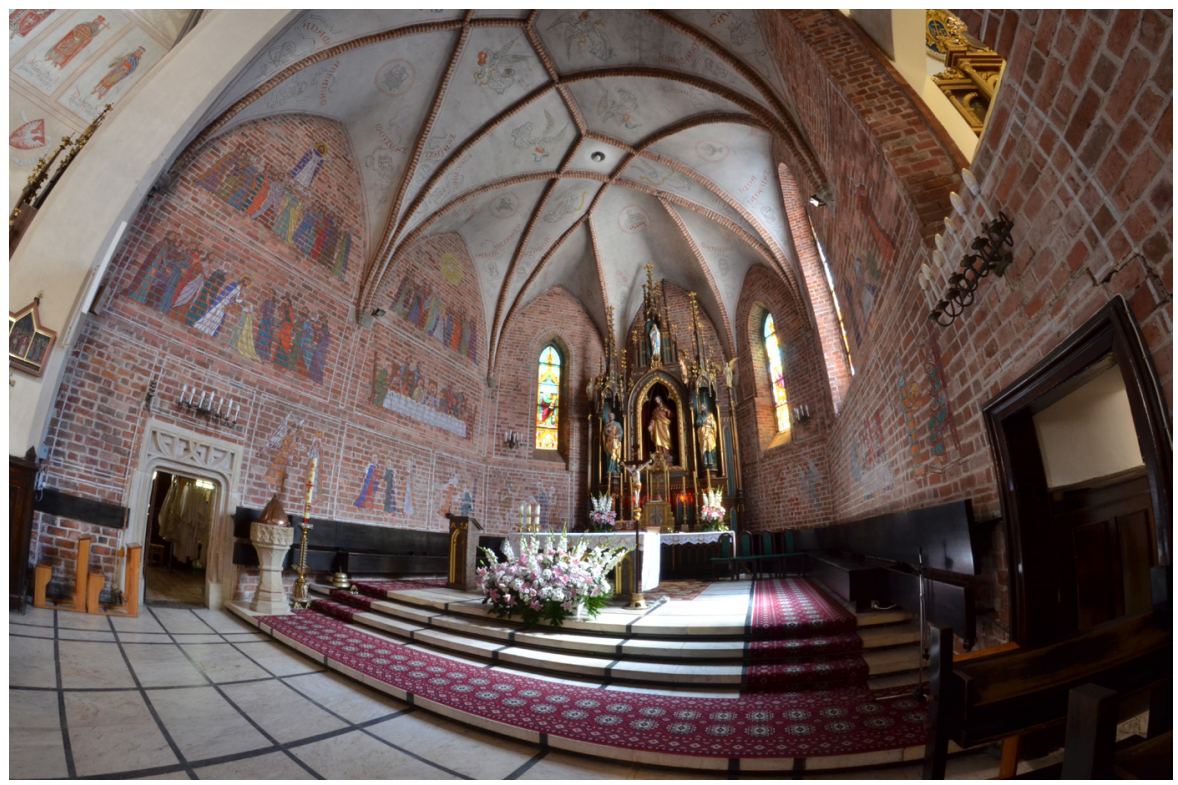

Il. 1. Kościół pw. św. Jana Chrzciciela w Radomiu. Widok wnętrza prezbiterium z polichromią ścienną autorstwa W. Taranczewskiego. Fot. Adrian Lament

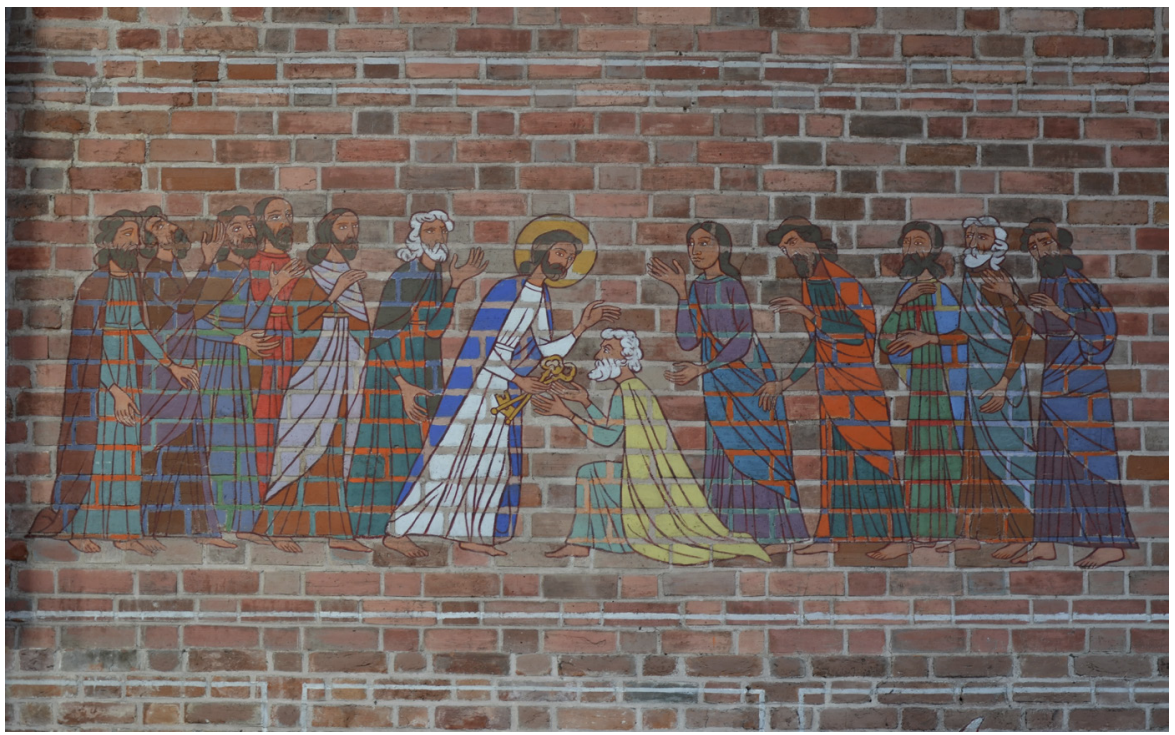

Il. 2. Kościół pw. św. Jana Chrzciciela w Radomiu. „Wręczenie kluczy św. Piotrowi” - malowidło ścienne projektu W. Taranczewskiego na północnej ścianie prezbiterium. Fot. Adrian Lament 


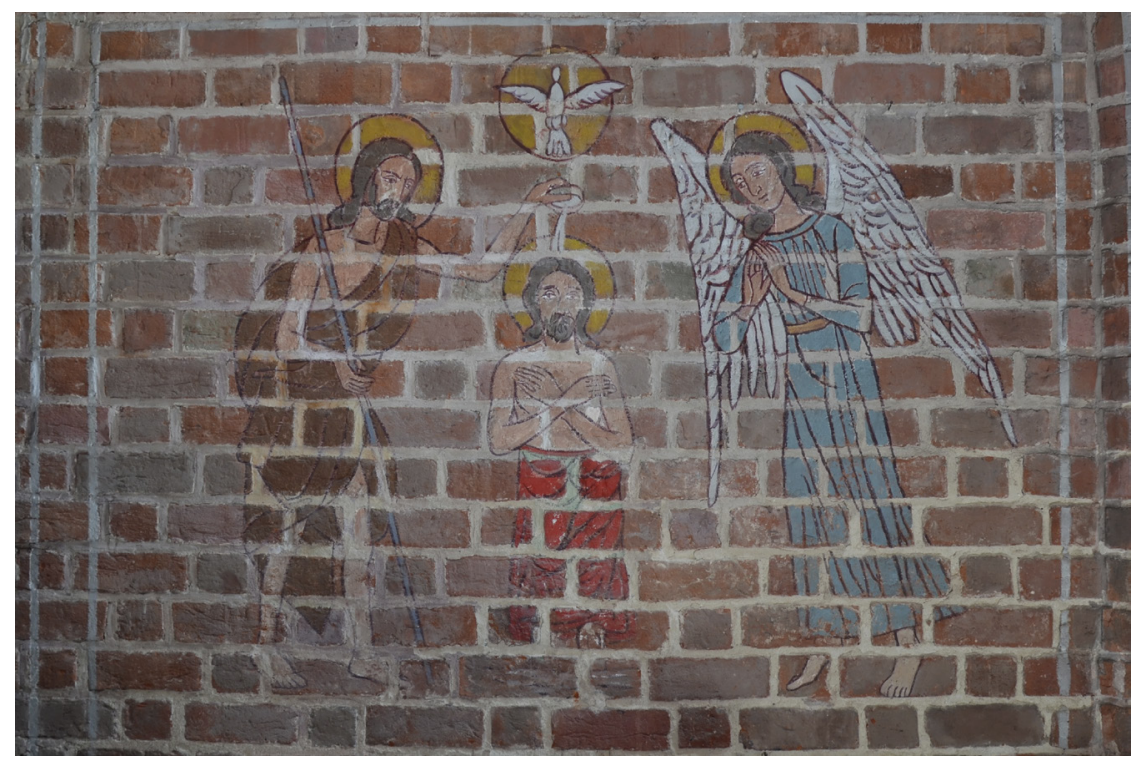

Il. 3. Kościół pw. św. Jana Chrzciciela w Radomiu. „Chrzest Jezusa w Jordanie” - malowidło ścienne projektu W. Taranczewskiego na południowej ścianie prezbiterium. Fot. Adrian Lament

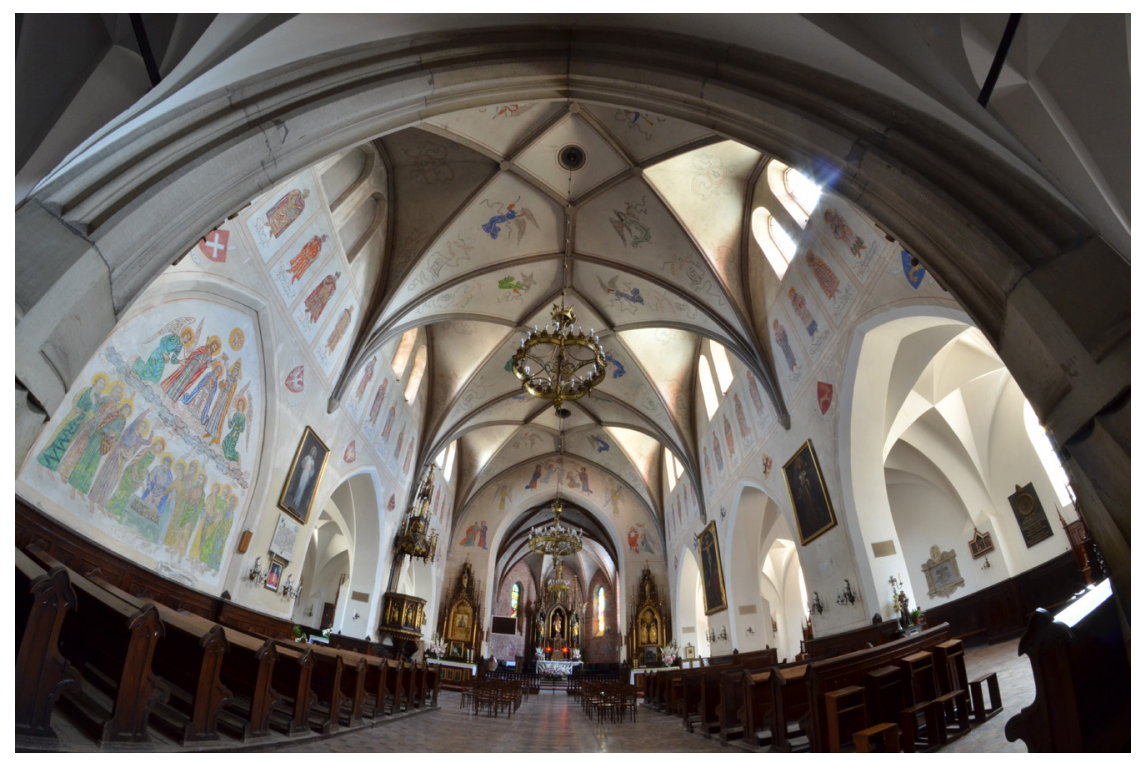

Il. 4. Kościół pw. św. Jana Chrzciciela w Radomiu. Widok wnętrza nawy głównej z polichromią ścienną autorstwa W. Taranczewskiego. Fot. Adrian Lament 


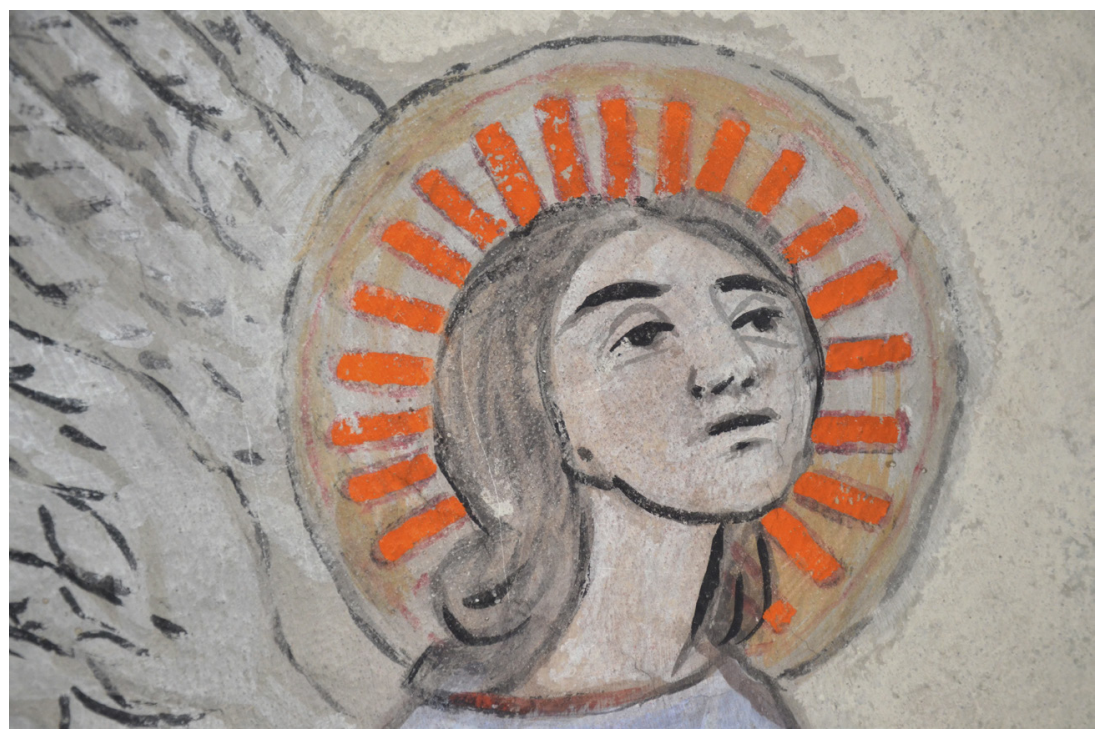

Il. 5. Kościół pw. św. Jana Chrzciciela w Radomiu. „Ukrzyżowanie” - fragment malowidła na ścianie tęczowej. Fot. A. Lament-Kosińska

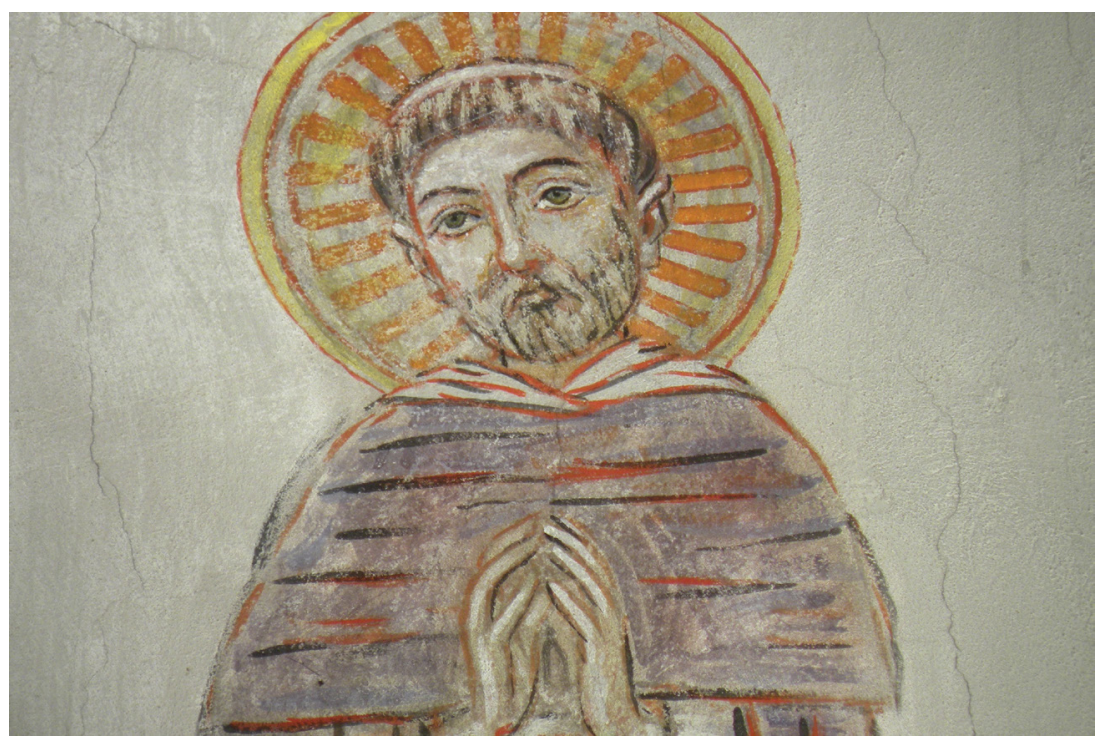

Il. 6. Kościół pw. św. Jana Chrzciciela w Radomiu. Błogosławiony Czesław - fragment przedstawienia z południowej ściany pierwszego przęsła nawy głównej. Fot. A. Lament-Kosińska 


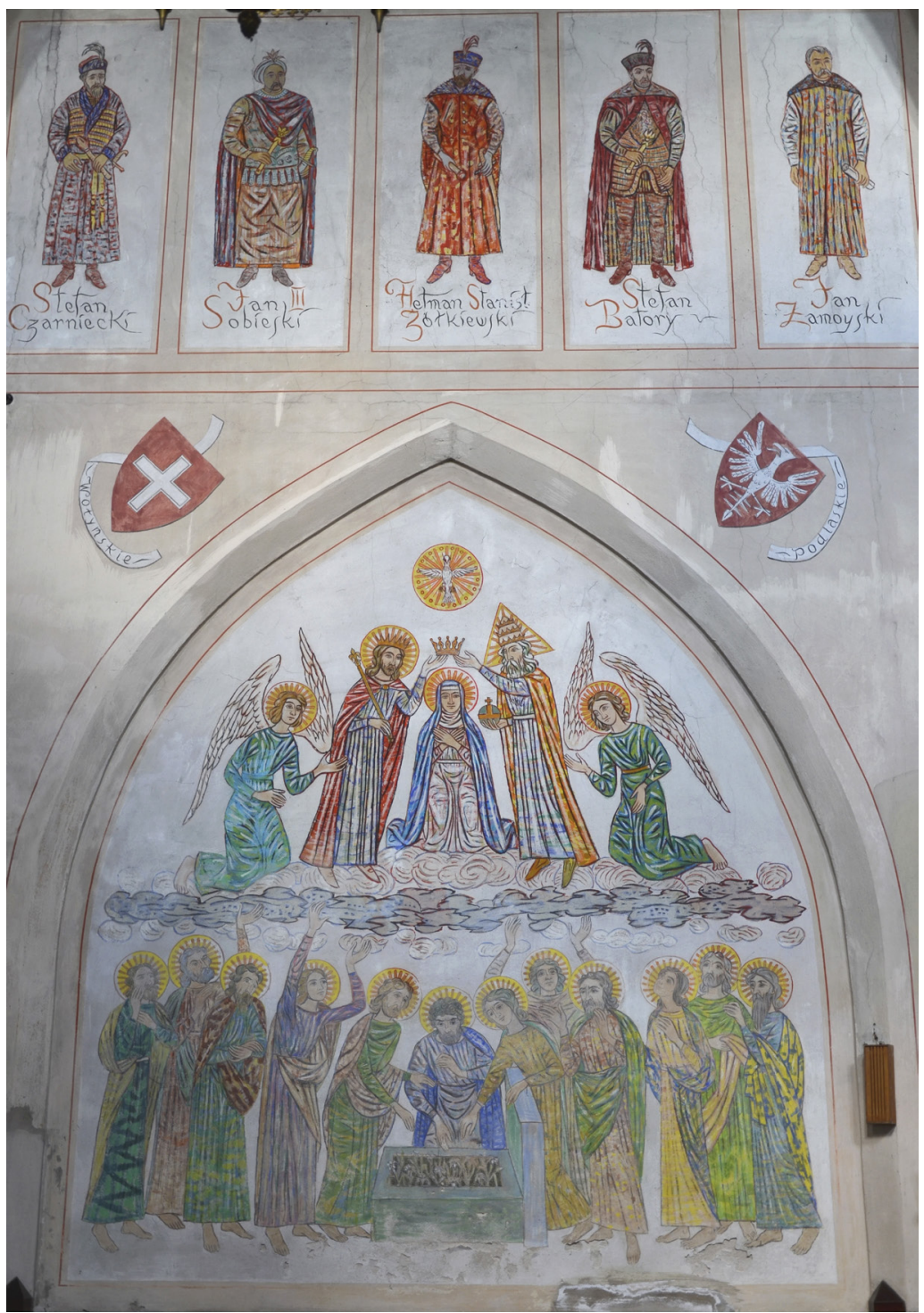

Il. 7. Kościół pw. św. Jana Chrzciciela w Radomiu. „Wniebowzięcie Najświętszej Marii Panny” oraz fragment fryzu z postaciami królów, książąt, świętych i błogosławionych na północnej ścianie trzeciego przęsła nawy głównej. Fot. Adrian Lament 